\title{
Current Reading Habits of Higher Vocational College Students in Zhejiang Technical Institute of Economics
}

\author{
Yongliang Xie \\ Logistics and Supply Chain Management School,Zhejiang Technical Institute of Economics \\ 66 Xue Zheng Street,Hangzhou,310018, Zhejiang,China
}

\begin{abstract}
This study employed a convergent mixed-method research design to investigate current reading habits of college students and its impact on their lives in Zhejiang Technical Institute of Economics from China. A total of 456 (285 male and 171 female) college students voluntarily participated in the study by completing a selfreported survey. 50 students participated in semi-structured interviews and classroom observations. Descriptive analysis indicated that the hours students spent weekly (M) on academic reading (AR), extracurricular reading (ER), and the Internet (INT), part-time job(PJ), socializing with others(SO) and sleeping (SL)were 10.15, 14.42 , 9.39,19.97and 57.15 respectively.too much PJ and INT can affect learning outcomes, sleeping, interpersonal relationships, mood and cognitive activities.More than half of the students believe that new media reading has both advantages and disadvantages for their life and study, which depends on self-management.College students' reading behavior has obvious digital features, but the traditional paper reading is still retained and continued.Students are also eager for teachers to teach professional literature reading skills to avoid wasting too much time on ineffective reading.
\end{abstract}

Keywords:Reading, Reading Habits, Vocational College Students

DOI: $10.7176 / \mathrm{JEP} / 12-15-01$

Publication date:May $31^{\text {st }} 2021$

The research is financed supported by "13th Five-Year Plan" Zhejiang Province Higher Education Reform Research Project "Research and Practice of Improving the Literature Reading Ability of Students majoring in Logistics Management of Higher Vocational Education at Different Levels" (JG20180779) .

\section{Introduction}

Reading has long been regarded as an important skill throughout life (Allen, etal.,1992).The academic reading ability is one of the core indicators of college students' professional ability, and it is also the basis of cultivating innovative ability.Evidence shows that students' academic reading ability comes from reading more, cultivating reading interest and teaching reading strategies (Chen, 2007;Mokhtari etal., 2009;Suhua Huang, 2014).

In the past decade or so, mobile Internet have seriously impacted traditional media such as newspapers, radio and television, and significantly changed the reading behavior, habits and psychology of college students (Emanuel et al., 2008; Guenthner \& Swan, 2011).College students are the main group of digital reading, which has the characteristics of browsing, fast food, casual and fragmentation (Chai YL,2016).

Previous reading surveys mainly focused on hours spent on reading per week (Mokhtari et al.2009; Suhua Huang et al.2014), the most popular reading materials (Gallik, 1999), the difference in reading volume between majors (Jeffries and Atkins, 1996), the selection characteristics of electronic materials and paper materials (Ye Mengliang et al.,2018), but not enough to fully understand the current vocational students' reading behavior, which is the purpose of this survey, in order to help formulate and improve students' professional literature reading strategies.

\section{Methods and Instrument}

This study used a mixed-method research design;both quantitative and qualitative data were collected simultaneously but individually.A total of 456(285 male and 171 female) students of different grades from three majors in School of Logistics and Supply Chain Management at ZJTIE voluntarily participated in the study by completing a self-reported survey, and 50 students of them participated in semi-structure interviews and classroom observation twice a week.The data was analyzed with SPSS 20.0. Enumeration data were represented by the number of cases and composition ratio, and the chi-square test was used, with the test level $\alpha=0.05$.

Survey and interview content mainly include information channels, network type, the influence of network for reading and life, and hours spent on different activities including academic reading, extracurricular reading, a part-time or full-time job, Internet (browsing websites)each week , sleeping, and socializing with others, material type which are more willing to read, the main reading place, a single continuous reading time and the main influence factors and so on.

The classroom observation notes recorded in detail the use of the Internet, reading attitude, reading pattern, reading ability, and the effectiveness of using the Internet to complete class assignments and group discussions 
of 50 students during one semester.

\section{Survey questions and results}

\section{Q.1 Overview of college students' reading behavior}

Table 1 shows that mobile phones and computers are the main channels for college students to obtain information, accounting for $92.11 \%$ and $83.33 \%$ respectively. $66.9 \%$ of the students use wireless network, and $100 \%$ of the students consider digital reading as the main way of reading. As the popularity of $5 \mathrm{G}$ technology in China has led to a drop in the price of data traffic , more and more students are inclined to use Internet for reading.College students of different grades surf the Internet in different ways. The higher the grade, the more college students use WiFi, and the difference is statistically significant $\left(\mathrm{X}^{2}=16.73, \mathrm{P}<0.05\right) .95 .2 \%$ of students think that the Internet has a great impact on study and life.

Table 1.Overview of College Students' Reading Behavior

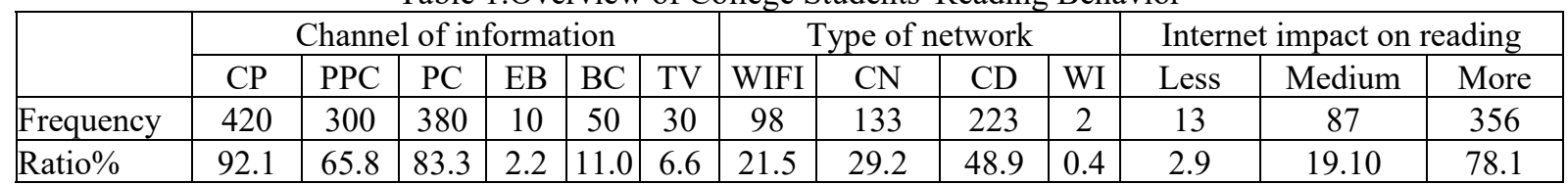

Note. $\mathrm{CP}=$ Cellphone, $\mathrm{EB}=$ extracurricular book, $\mathrm{BC}=$ Broadcast, $\mathrm{CN}=\mathrm{Cable}$ Network, $\mathrm{CD}=\mathrm{Cellphone}$

data, $\mathrm{WI}=$ Without internet

91\% of the students' eyesight was affected by mobile phones, computers and other electronic products, together with $57 \%, 41.4 \%$ soreness and $78.9 \%$ respectively. $96 \%$ of the students believed that their skin deteriorated varying with time of using electronic products. $19.9 \%$ of the students have imitated their violent behaviors by online novels and games. Even though $90 \%$ of the students oppose online violence, $17.98 \%$ of the students still hold an indifferent or understandable attitude to it. Only $9.2 \%$ of students think the Internet has more harm than good to their lives. Non heavy Internet users had better relationships with administrative staff, academic grades, and learning satisfaction than heavy Internet users. Heavy users were more likely than nonheavy Internet users to be depressed, physically ill, lonely, and introverted for much difficulties with homework.

Q.2 Time Spent in Academic Reading (AR), Extracurricular Reading (ER), and Internet use (INT),Parttime Job(PJ)、Socializing with others(SO)、Sleeping(SL)

Table 2 presents the means and standard deviations for the amount of time the respondents reported spending on AR, ER,INT,PJ,SO,SL use.Results indicated that the most time spent on AR, ER, INT, PJ, SO and SL was 42.98\% (0-6 hours), 34.65\% (7-12 hours), 41.45\% (13-18 hours), 46.05\% (7-12 hours), 39.25\% (19-24 hours) and $100 \%$ (over 30 hours ) respectively. The average weekly time spent on AR, ER, INT, PJ, SO and SL was 10.15 hours, 14.42 hours, 17.09 hours, 9.39 hours, 19.97 hours and 57.15 hours, respectively. $98 \%$ of the students think that digital reading affects their sleep, and $91.9 \%$ of the students play with mobile phones or computers before sleeping. $78.7 \%$ of students spend $7 \mathrm{~h}-21 \mathrm{~h}$ per week for the Internet, and that the higher the grade, the higher the frequency of using the Internet for more than 4 hours per $\operatorname{day}\left(\mathrm{X}^{2}=18.62, \mathrm{P}<0.05\right)$.

Table 2.Time Spent Weekly on AR,ER,INT ,PJ,SO, and SL

\begin{tabular}{lllllllll}
\hline & $0-6 \%$ & $7-12 \%$ & $13-18 \%$ & $19-24 \%$ & $25-30 \%$ & $>=30 \%$ & M & SD \\
\hline AR & 42.98 & 20.39 & 24.34 & 7.68 & 2.85 & 1.75 & 10.15 & 1.14 \\
ER & 10.97 & 34.65 & 28.73 & 13.16 & 10.09 & 2.41 & 14.42 & 1.57 \\
INT & 1.1 & 11.00 & 46.1 & 26.5 & 12.16 & 3.24 & 18.20 & 2.91 \\
PJ & 32.90 & 46.05 & 10.53 & 6.36 & 2.85 & 1.32 & 9.39 & 1.44 \\
SO & 6.36 & 7.46 & 19.52 & 39.25 & 24.56 & 2.85 & 19.97 & 3.42 \\
SL & 0 & 0 & 0 & 0 & 0 & 100 & 57.15 & 7.32 \\
\hline
\end{tabular}

Note. $\mathrm{M}=\mathrm{Mean}, \mathrm{SD}=$ Standard deviation, $\mathrm{AR}=$ academic reading, $\mathrm{ER}=$ extracurricular reading, $\mathrm{INT}=$ Internet,

$\mathrm{PJ}=$ Part-time $\mathrm{Job}, \mathrm{SO}=$ Socializing with others, $\mathrm{SL}=$ Sleeping

The findings found that part-time jobs and the Internet, including social networking websites, could reduce the amount of time students dedicated to both academic and extracurricular reading.

Part-time jobs mainly consisting of assistant, student union leader and off-campus part-time jobs reduce college students' reading time.56\% of respondents work 7-15 hours a week.Part-time jobs can improve problem solving and communication skills but reduce study time for them.Too many part-time jobs reduce learning efficiency and reading capacity, resulting in late attendance, absenteeism, drowsiness in class, and passive participation in class activities.

The majority of students said that they had positive attitudes toward the use of the Internet and its applications, which have multiple functions in improving their personal and academic lives, such as connecting with others, meeting new friends, searching for new information,completing group projects, and even sharing study notes and class assignments.

But it makes it easy for students to become addicted to the Internet, stare at their cell phones almost all day 
and feel anxious for missing out on information.Other students take part-time "on-call" jobs for losing the opportunity to earn extra money.94.5\% of the students felt that the Internet had caused them to lose their concentration in class.Only $7.7 \%$ of the students used cellphones to read related content in class. $83.3 \%$ of students communicated with others on social application.In general, the seniors spent more time online than the juniors, and boys spent more time online than girls.Some students surfed the Internet under the influence of their classmates.

The practice of network teaching has changed students' reading habits.Students tend to read PPTs online only before or after class, rather than carefully reading textbooks."Reading paper textbooks is boring and timeconsuming" and "reading PPT is equivalent to reading textbooks" became the mainstream consciousness.

Classroom observation notes also proved that smart cellphones have brought many problems to students, such as sending emails, chatting online, video sharing and video games during class. As a result, students took no textbooks,pens and notes, and answer irrelevantly and absent mind when answering questions in class.

Q.3 What kind of materials did college students prefer to read: online reading materials, magazines/newspapers, non-academic books, bestseller/traditional novels?Electronic text or regular text?How does it affect students' reading practice?

To describe the frequency of four types of extracurricular reading: online reading materials, magazines/newspapers, non-academic books, bestseller/traditional novels, 1 was assigned to never, 2 to seldom, 3 to sometimes, and 4 to frequently.Table 3 summarized the percentage distribution of students' interest in reading.The most common response to online reading material was "frequently" (39.3\%).For non-major academic books, "frequently" was the lowest (5\%) and "never" was the highest (45.2\%).Overall, the results indicated students enjoyed online reading materials. Online reading material was the most popular type of reading material,closely followed by bestseller/traditional novels,Magazines and newspapers ,Non-major academic books.

Table 3.Descriptive Response to Reading Interests

\begin{tabular}{ccccccc}
\hline & Never $\%$ & Seldom $\%$ & Sometimes $\%$ & Frequently $\%$ & M & SD \\
\hline Online reading & 3.7 & 24.8 & 32.2 & 39.3 & 3.07 & 0.66 \\
Magazines/newspapers & 19.5 & 40.4 & 27.6 & 12.5 & 2.33 & 0.30 \\
Bestseller/novels & 21.9 & 34.0 & 30.0 & 14.0 & 2.36 & 0.28 \\
Non-major academic books & 45.2 & 37.1 & 12.7 & 5.0 & 1.78 & 0.22 \\
\hline
\end{tabular}

Note. $\mathrm{M}=\mathrm{Mean}, \mathrm{SD}=$ Standard deviation

$56.79 \%$ of responses spent less time on traditional reading than on online reading, $66 \%$ of them thought that traditional reading was more focused, and that leisure and entertainment information and Domestic and international news were the main contents of online reading, $94.9 \%$ and $91 \%$ respectively. The types of traditional reading materials were mainly classical literature works, entrance examination materials and professional literature materials, accounting for $71.9 \%, 68 \%$ and $79.2 \%$ respectively(see Table 4 ).As far as the content of reading was concerned, girls preferred to leisure and entertainment than boys in both traditional reading $\left(X^{2}=9.86\right.$, $\mathrm{P}<0.05)$ and online reading $\left(\mathrm{X}^{2}=6.34 . \mathrm{P}<0.05\right)$.

Table 4.Content Comparison of Online Reading and Traditional Reading

\begin{tabular}{lcccccccc}
\hline & $\begin{array}{l}\text { Online } \\
\text { reading }\end{array}$ & $\begin{array}{c}\text { Traditional } \\
\text { paper reading }\end{array}$ & Never & Seldom & Sometimes & Frequently & M & SD \\
\hline Classical literature & $28.1 \%$ & $71.9 \%$ & $21.9 \%$ & $34.0 \%$ & $30.0 \%$ & $14.0 \%$ & 2.36 & 0.28 \\
News information & $91 \%$ & $9 \%$ & $3.7 \%$ & $24.8 \%$ & $32.2 \%$ & $39.3 \%$ & 3.07 & 0.66 \\
$\begin{array}{l}\text { Bestseller/novels } \\
\text { Test Material }\end{array}$ & $67 \%$ & $33 \%$ & $21.9 \%$ & $34.0 \%$ & $30.0 \%$ & $14.0 \%$ & 2.36 & 0.28 \\
$\begin{array}{l}\text { Leisure and } \\
\text { entertainment }\end{array}$ & $94.9 \%$ & $68 \%$ & & & & & & \\
$\begin{array}{l}\text { Professional } \\
\text { literature }\end{array}$ & $20.8 \%$ & $79.2 \%$ & $3.7 \%$ & $24.8 \%$ & $32.2 \%$ & $39.3 \%$ & 3.07 & 0.66 \\
\hline
\end{tabular}

Note. $\mathrm{M}=\mathrm{Mean}, \mathrm{SD}=$ Standard deviation

According to the survey, most students agreed that the Internet has a positive impact on their studies and often use search engines (90\%) and professional literature websites (10\%) to complete various assignments.Due to providing functions such as amplification, translation, note-taking, searching, highlighting, copying, and pasting, with the addition of their features with more cheaper and easier to carry, e-books were more popular with students.Audio, video and image information were also popular formats for students to read.

Interviews and classroom observations also proved that students tended to copy and paste others' works to complete assignments because it was easier to find online resources than traditional paper resources. 
Q.4 Under what circumstances did reading have most efficiency?How long is one reading session?What factors affect reading?

Table 5 manifested that $30.04 \%$ of students used to selective reading, while only $3.51 \%$ chose deep reading.nearly $80 \%$ regarded library as the best learning environment, but library space was insufficient. $43.40 \%$ preferred reading digitally in their dormitory, but their roommates played games and watched movies, which seriously effect their reading efficiency.Only $17.32 \%$ of students would not give up the original reading content because other information spring out on the page when reading digitally (see Table 6).Different grades of students chose different places for online reading. Higher grades preferred to read online in the library $\left(\mathrm{X}^{2}=30.73\right.$. $\mathrm{P}<0.05$ ), and $99 \%$ of freshmen went to the classroom to read at night required by the school.From the perspective of the duration of a single reading, it was generally about 30-40 minutes without interference.

Table 5. Survey of Reading Behavioral Characteristics and Places

\begin{tabular}{|c|c|c|c|}
\hline Survey items & Mode Choice & Frequence & $\%$ \\
\hline \multirow{4}{*}{ Behavioral characteristics of online reading } & Browse & 215 & 47.15 \\
\hline & Selective reading & 137 & 30.04 \\
\hline & One-time reading & 88 & 19.30 \\
\hline & Deep reading & 16 & 3.51 \\
\hline \multirow{3}{*}{$\begin{array}{l}\text { Abandoning the initial content because othe } \\
\text { information appeared on the page }\end{array}$} & Frequently & 102 & 22.37 \\
\hline & Sometimes & 275 & 60.31 \\
\hline & Never & 79 & 17.32 \\
\hline \multirow{4}{*}{ Reading place (multiple choice, $n=456$ ) } & Bedroom & 456 & 43.40 \\
\hline & Library & 133 & 17.30 \\
\hline & Classroom & 201 & 13.70 \\
\hline & Outdoor & 245 & 18.00 \\
\hline
\end{tabular}

Although $42.1 \%$ of college students often use online reading, $70.2 \%$ of them will choose traditional paper reading if conditions permit, the biggest reason(46.1\%)was that they can deep reading. The biggest reason for choosing online reading was the convenience of accessing and reading, accounting for $30.8 \%$ (multiple choices);Leisure and entertainment was the biggest reason for college students to choose online reading, accounting for $57.5 \%$, followed by access to information, accounting for $23.7 \%(108 / 456)$ (see Table 6 ).

Table 6. Difference Between Reading Mode Choices and Reason

\begin{tabular}{|c|c|c|c|}
\hline Survey items & Mode Choice & Frequence & $\%$ \\
\hline \multirow{3}{*}{ Reading mode choice } & Traditional reading & 159 & 34.9 \\
\hline & Online reading & 192 & 42.1 \\
\hline & No particular preference & 105 & 23.0 \\
\hline \multirow{2}{*}{ If conditions allow, the choice of reading mode } & Traditional reading & 320 & 70.2 \\
\hline & Online reading & 136 & 29.8 \\
\hline \multirow{4}{*}{ Motivation for choosing online reading } & Studying & 31 & 6.8 \\
\hline & Leisure \& entertainment & 262 & 57.5 \\
\hline & Accessing to information & 108 & 23.7 \\
\hline & Aimless reading & 55 & 12.1 \\
\hline \multirow{2}{*}{ Selection of reading materials } & Traditional paper materials & 264 & 57.9 \\
\hline & Digital material & 192 & 42.1 \\
\hline \multirow{4}{*}{ Reasons for choosing traditional paper sources } & Reliable Information & 91 & 20.0 \\
\hline & Intensive reading & 210 & 46.1 \\
\hline & Easy to save & 49 & 10.7 \\
\hline & Personal interests & 106 & 23.2 \\
\hline \multirow{6}{*}{$\begin{array}{l}\text { Reasons for choosing Digital sources } \\
\text { (multiple choice) }\end{array}$} & Large amount of information & 102 & 7.6 \\
\hline & Low cost & 301 & 22.3 \\
\hline & Easy to get and read & 415 & 30.8 \\
\hline & Strong autonomy and selectivity & 235 & 17.4 \\
\hline & Fast update speed & 89 & 6.6 \\
\hline & Existing habits driving & 388 & 28.8 \\
\hline
\end{tabular}

\section{Q.5 Reasons for the lack of academic reading}

The survey found that $67.32 \%$ of the interviewees did not know the skills and strategies of academic reading, among which $83 \%$ of the freshmen from vocational high schools did not know the significance of academic reading, also did not know how to use library database and how to carry out academic reading. $38 \%$ of respondents showed no interest or motivation to read academic literature, especially periodicals, unless teachers 
assign related homework, only a few teachers assigned some related extracurricular literature reading tasks ,69\% of the students said they wanted to read professional literature, but gave up reading when they couldn't understand the relative knowledge, and rarely asked teachers for advice.

\section{Discussion}

The results showed that the Internet has changed college students' read behaviors.Online reading materials, such as e-books, online library databases, video and audio media, are the most common reading materials for college students, and their interest in reading has shifted from traditional reading to digital text reading.

Students will use the Internet such as searching for e-books/periodicals, news or information related to academic reading to complete assignments, as well as online interactive applications like QQ and WeChat to share assignments and complete team projects. The widespread use of the Internet has improved their social skills, information literacy skills and learning process, but it has also greatly affected the time available for active academic and extracurricular reading activities.

Students' part-time work intensity is negatively correlated with their attention in class, their effort in school and their attendance.A full load of part-time jobs encroaches on students' sleep time, and fatigue can affect students' reading activities and reduce their motivation to participate in academic and extracurricular activities.

Although Internet technology has promoted the emergence of educational practice forms such as "eteching" and "e-learning", it also has a negative impact on students' studies. For example, students simply copy and paste the results of online search and submit them as homework without careful reading and thinking.For example, during class, some students are too busy chatting in real time or watching videos to listen to the class.In fact, Internet technology cannot replace effective teaching practices. Teachers still have a great influence on college students' reading interest and motivation, so they still need to guide and encourage college students to carry out academic reading activities independently.

\section{Implication}

Understanding the college students' reading behavior helps teachers to learn more about the students' education requirements. The study confirms that Internet technology has changed teaching activities. Teachers need to recognize the impact of modern technology on reading habits of college students, including adaptive technology, which enables the ability of education environment to explore the method of learning, provide convenient and interesting reading materials, and use appropriate incentive strategies to promote academic reading practice, critical thinking and creative activities in digital environment, and the sense of satisfaction and pleasure.

Although this study used small sample data from ZJTIE, it gave us general pictures about college students' online behavior and its consequences.Hopefully, the findings of this study will stimulate more research and indepth exploration into the area of students' Internet use .

\section{References}

Allen, L., Cipielewski, J., \& Stanovich, K. E. (1992). Multiple indicators of children's reading habits and attitudes: Construct validity and cognitive correlates. Journal of Educational Psychology, 84, 489-503.

Applegate, A. J., \& Applegate, M. D. (2004). The Peter effect: Reading habits and attitudes of preservice teachers. The Reading Teacher, 57, 554-563.

Chen, S. Y. (2007). Extracurricular reading habits of college students in Taiwan: Findings from two national surveys. Journal of Adolescent \& Adult Literacy,50(8), 642-650.

Chai YL(2016).Research on college students' new media reading status,influencing factors, and methods for improvement: survey of 5 universities on the current situation and demand of university students' digital reading. Education Research, 22(2): 71—72. DOI:10.13966/j.cnki.kfjyyj.2016.02.008.

Emanuel, R., Adams J., Baker, K., Daufin, E. K., Ellington, D. C., Fitts, E.,...Okeowo, D. (2008). How college students spend their time communicating. The INTL. Journal of Listening, 22, 13-28.

Gallik, J. D. (1999). Do they read for pleasure? Recreational reading habits of college students. Journal of Adolescent \& Adult Literacy, 42, 480-489.

Guenthner, J. F., \& Swan, B. G. (2011). Extension learners use of electronic technology. Journal of Extension, $49,1-9$.

Jeffries, L., \& Atkins, D. J. (1996). Dimensions of student interest in reading newspaper. Journalism and Mass Communication Educator, 51(3), 12-23.

Jones, S., Johnson-Yale, C., Millermaier, S., \& Perez, F. S. (2008). Academic work, the Internet and U.S. college students. Internet and Higher Education, 11, 165-177.

Mokhtari, K., Reichard, C., \& Gardner, A. (2009). The impact of Internet and television use on the reading habits and practices of college students. Journal of Adolescent \& Adults Literacy, 92(7), 609-619.

Pressley, M. (2002). Reading instruction that works: The case for balanced teaching(2nd ed). New York, NY: Guilford Press. 
SuHua Huang, Matthew Capps, Jeff Blacklock \& Mary Garza (2014).Reading Habits of College Students in the United States, Reading Psychology, 35:5, 437-467, DOI: 10.1080/02702711.2012.739593

Ye.Mengliaug,Luo Yetao, Ou Rong(2018).A study on the reading behavior of college students in Chongqing under the new media. Chinese Journal of Medical Education Research.17(1):96-100. 